\title{
Gall-forming insect attack patterns: a test of the Plant Vigor and the Resource Concentration Hypotheses
}

\author{
Juliana Tuller ${ }^{1 *}$ \\ Antônio César Medeiros de Queiroz ${ }^{1}$ \\ Giovana Rodrigues da Luz $^{2}$ \\ Jhonathan de Oliveira Silva ${ }^{3}$ \\ 'Setor de Ecologia e Conservação, Universidade Federal de Lavras \\ Campus Universitário, Caixa Postal 3037, CEP 37200-000, Lavras - MG, Brasil \\ ${ }^{2}$ Centro de Estudos de Convivência com o Semiárido, Universidade Estadual de Montes Claros \\ Avenida Ruy Barbosa, CEP 3940 1-089, Montes Claros - MG, Brasil \\ ${ }^{3}$ Laboratório de Interações Tri-tróficas, Departamento de Ecologia, Instituto de Ciências Biológicas \\ Universidade de Brasília, Campus Universitário Darcy Ribeiro, CEP 70910-900, Brasília - DF, Brasil \\ *Corresponding author \\ julianatullerm@gmail.com
}

Submetido em 29/05/2012

Aceito para publicação em 01/10/2012

\section{Resumo}

Padrões de ataque de galhadores: um teste das hipóteses do vigor da planta e da concentração de recursos. Nós testamos duas hipóteses para investigar os padrões de ataque de insetos galhadores na planta hospedeira Eriotheca pubescens: (i) módulos mais vigorosos são mais atacados por insetos galhadores; (ii) indivíduos de $E$. pubescens em maiores densidades de indivíduos co-específicos possuem uma maior abundância de galhas. Nós coletamos ramos terminais da planta hospedeira para mensurar o comprimento dos seus módulos e a riqueza e abundância de galhadores. Nós determinamos a densidade de E. pubescens em um círculo com $5 \mathrm{~m}$ de raio em torno do indivíduo focal. Houve uma maior disponibilidade de ramos curtos. Dentre os quatro morfotipos de galhas avaliados, dois preferiram ramos longos e outros dois não apresentaram preferência por um determinado tamanho de ramo. $\mathrm{O}$ ataque de galhadores não apresentou relação com a densidade de plantas hospedeiras. Então, o vigor da planta foi um fator determinante, para o ataque de galhas em E. pubescens. Por outro lado, a hipótese da concentração de recursos não foi importante em nível intra-específico para o ataque de galhas nesse sistema.

Palavras-chave: Comprimento do módulo; Embiruçu; Eriotheca pubescens; Inseto galhador

\section{Abstract}

We tested the following two hypotheses to investigate the attack patterns by gall-inducing insects on their host plant Eriotheca pubescens: (i) vigorous modules are more often attacked by galling insects; and (ii) $E$. pubescens trees associated with a higher density of co-specific individuals have a higher gall abundance. We collected terminal branches from the host plant to measure their module lengths and gall richness and abundance and determined the E. pubescens densities in a $5 \mathrm{~m}$ radius around the focal individual. There was a higher availability of short branches. Among the four gall morphotypes, two preferred the higher branches, and the other 
two morphotypes had no shoot length preference. Gall attack did not present a relationship with the host plant density. Thus, the vigor of E. pubescens was a determining factor only for some gall morphotypes. In contrast, the resource concentration hypothesis was not important at an intraspecific level for gall attack in this system.

Key words: Embiruçú; Eriotheca pubescens; Gall-inducing insect; Plant module size

\section{Introduction}

Galls are morphological changes caused by endoparasites, mainly insects, and can be found on any organ of the host plant. Among these insects, the order Diptera (Cecidomyiidae) presents a particular richness and abundance of gall-forming species (FERNANDES; MARTINS, 1985; FERNANDES et al., 1997; CARNEIRO et al., 2009). In general, gall-inducing insects are influenced by several host plant traits, including nutritional quality (GONÇALVES-ALVIM; FERNANDES, 2001; CUEVAS-REYES et al., 2004), architecture (ESPÍRITOSANTO et al., 2007; COSTA et al., 2010), developmental stage (CAMPOS et al., 2006; COSTA et al., 2011) and plant vigor (PRICE, 1991; CORNELISSEN; FERNANDES, 2001; CORNELISSEN et al., 2008; SANTOS et al., 2008; SANTOS; FERNANDES, 2010; JESUS et al., 2012). Moreover, plant density and richness may determine gall-inducing preference and performance (ROOT, 1973; CUEVAS-REYES et al., 2004; FLECK; FONSECA, 2007).

As such, several ecological hypotheses have been proposed to explain the patterns of gall attack on their host plants (FERNANDES; PRICE, 1988; FLECK; FONSECA, 2007; INBAR et al., 2010). Due to the high specificity for its host plants and sessile habit during the larval phase (CUEVAS-REYES et al., 2004; CARNEIRO et al., 2009), the guild of gall-inducing species is considered an important tool to test hypotheses about insect-plant interactions. The plant stress hypothesis (PSH - WHITE, 1974) proposes that stressed plants are more attacked than others due to changes in plant physiology, such as higher nutrient concentration and decreased concentration of defensive compounds and/or changes in the ratio of nutrients to chemical defenses (WHITE, 1984). Tests of this hypothesis have contradictory results, sometimes not presenting any relationship between insect abundance and plant stress (HUBERTY; DENNO, 2004). An alternative hypothesis to $\mathrm{PSH}$ is the plant vigor hypothesis $(\mathrm{PVH})$, which predicts that insect herbivores select more vigorous plants or modules because they have new tissues with a high nutritional content and provide better performance for offspring (PRICE, 1991). The resource concentration hypothesis has been tested to study the gall distribution patterns on patches of their host plant population. Initially proposed by Root (1973), this hypothesis predicts a higher gall abundance in patches with higher host plant densities. When this hypothesis is transferred to the intraspecific level, higher gall abundance may be found in patches with higher host plant densities because resources are more easily found by herbivores (FLECK; FONSECA, 2007).

In this study, we evaluated the interaction of gallinducing insects with their host plant and tested the PVH (PRICE, 1991) and the resource concentration (ROOT, 1973) hypothesis to explain the galling attack on Eriotheca pubescens (Mart. and Zucc.) Schott et Endl. (Malvaceae). This is the first study regarding plant-gall interactions for $E$. pubescens, an endemic tree species in the Brazilian Savanna. We predicted that (i) longer modules (more vigorous) present a higher gall abundance and (ii) there is higher gall abundance on $E$. pubescens trees within patches with a higher density of co-specific individuals.

\section{Material and Methods}

This study was conducted in a cerrado sensu stricto fragment (Brazilian Savanna) (16 $54^{\prime} 20^{\prime \prime}$ S and 43'53'07'W) of approximately 16 ha situated in Montes Claros, Minas Gerais, Brazil. The study site is located in the transition between the Cerrado and Caatinga biomes (RIZZINI, 1997). According to the Thornthwaite climate classification (THORNTHWAITE, 1948), the regional climate is dry sub-humid with marked dry and wet seasons during the year (ANTUNES, 1994). The average annual precipitation ranges from $733-1,305 \mathrm{~mm}$, with average 
annual temperatures from $16.8^{\circ} \mathrm{C}$ to $26.2^{\circ} \mathrm{C}$. The wet season occurs from October to March and the dry season from April to September (NIMER; BRANDÃO, 1989).

In June 2010, ten terminal branches were collected from 30 randomly selected trees. The sampled individuals had $4-9 \mathrm{~m}$ of height and a diameter at breast height $(\mathrm{DBH})$ equal to or greater than $10 \mathrm{~cm}$. We established a $5 \mathrm{~m}$ radius around each $E$. pubescens tree to calculate the host plant density (individuals $/ \mathrm{m}^{2}$ ), which was determined as a resource concentration for the gall morphotypes associated with E. pubescens. None of the selected trees was present in the $5 \mathrm{~m}$ radius around another one sampled. In the laboratory, all of the branch modules were measured, and the galls were counted and morphotyped according to their morphological traits (see CARNEIRO et al., 2009).

We first performed a Spearman correlation test between shoot length and leaf abundance to verify whether these variables are positively correlated, allowing the use of the shoot length as a resource abundance for leaf and stem galls. We considered each $1 \mathrm{~cm}$ of the branch as an available meristem for the female gall-forming insect to use as an oviposition site, as suggested by Faria and Fernandes (2001). Therefore, to examine whether the attack probability is higher for more vigorous branches, the branches were divided into $1 \mathrm{~cm}$ classes. Thus, the gall attack probability in the length class $i$ was obtained by the product of the number of galled branches on the total of branches available in class $i$ (FARIA; FERNANDES, 2001; SANTOS et al., $2008 ; 2010)$. We then analyzed the gall attack probability of each morphotype for the shoot length classes using generalized linear models (GLM). To test the resource concentration hypothesis, we constructed one model for each gall morphotype and its relationship with the host plant density. The models were tested against null models and followed by residual inspection to test for the suitability of the models and the error distribution (CRAWLEY, 2002). We used the Chi squared test with a Poisson error distribution, and we used the F test if the distribution was quasi-Poisson or quasiBinomial (see MCCULLAGH; NELDER, 1989). All of the analyses were performed in the software $R_{2.14}(R$ DEVELOPMENT CORE TEAM, 2011).

\section{Results and Discussion}

In total, we evaluated 300 E. pubescens shoots and counted 4672 galls distributed in five morphotypes all belonging to Cecidomyiidae. The gall morphotype abundances were as follows: M1 = 1969, M2 $=2521$, M3 = 116, M4 = 65 and M5 = 1 (Figure 1). Morphotype 5 was not included in any of the analyses because its abundance was only one. We found these five gall morphotypes associated with E. pubescens, but it is possible that this tree species has a higher richness due to its common presence in the Cerrado. M1, M2 and M3 induce leaf galls, whereas M4 and M5 induce shoot galls. Moreover, leaves were the plant organ most commonly attacked ( $98 \%$ of the total gall abundance). Together, M1 and M2 corresponded to $96 \%$ of the total gall abundance sampled. In general, the leaves have higher richness and abundance of galls than other plant organs, mainly due to the ease of sampling and conspicuousness upon observation (FERNANDES et al., 1988; COELHO et al., 2009; SANTOS et al., 2011). Nevertheless, leaves and branches are abundant resources and can provide oviposition support for the female insect throughout the year, resulting in a greater gall abundance and richness associated with this plant organ (FERNANDES et al., 1988).

The branch size ranged between $0.2 \mathrm{~cm}$ to $63 \mathrm{~cm}$, and the mean $( \pm \mathrm{SD})$ value was $19.62 \mathrm{~cm}( \pm 14.75)$. We observed a higher frequency of smaller branches (Figure 2), which is a common pattern found in other woody plants (PRICE, 1991; SANTOS et al., 2008; 2010).

We found a positive relationship between the percentage of galled shoots by morphotypes 1 and 3 and the shoot length classes (M1 - binomial, $\mathrm{F}=5.71$, $p=0.02$, D.F. $=57$; M3 - quasi-binomial, $F=6.70$, $p=0.01$, D.F. $=57$; Figure 2). Morphotypes 1 and 3 attack leaves, and vigorous branches were positively correlated with a greater number of leaves $(r=0.60$, $p<0.01$, D.F. $=57$ ), facilitating encounters with female adult insects and oviposition. Several studies have observed a positive relationship among these variables, mostly for cecidomyiids (KIMBERLING et al., 1990; CORNELISSEN et al., 2008; SANTOS; FERNANDES, 2010), and have related to a greater number of leaves 
FIGURE 1: Gall insect morphotypes associated with Eriotheca pubescens in a fragment of the Cerrado (Brazilian Savanna): a) morphotype 1; b) morphotype 2; c) morphotype 3; d) morphotype 4; and e) morphotype 5. Morphotypes 1 to 3 attack leaves, and morphotypes 4 and 5 attack shoots.

A

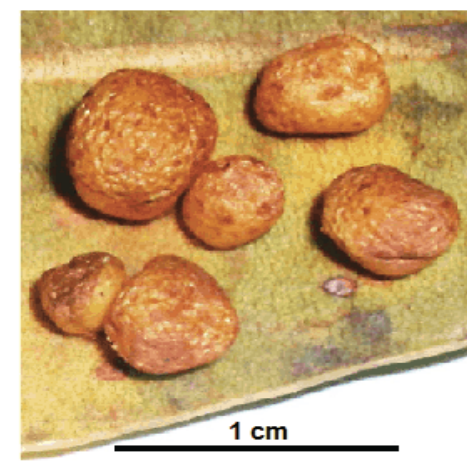

B

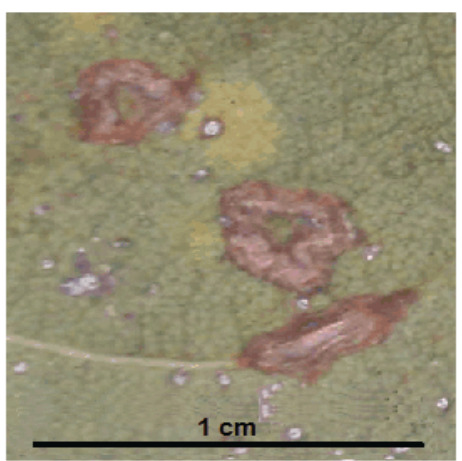

c

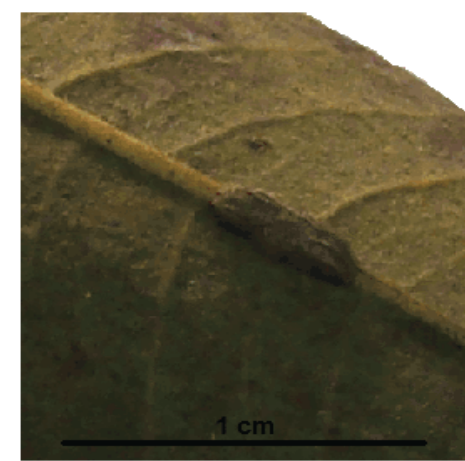

D

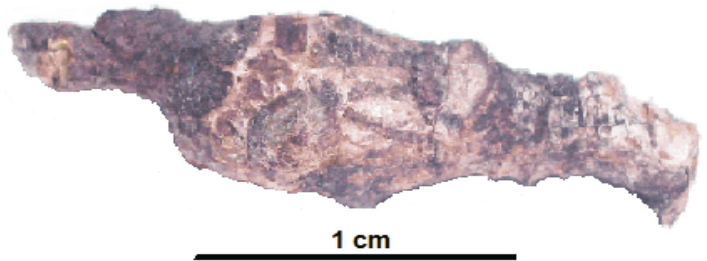

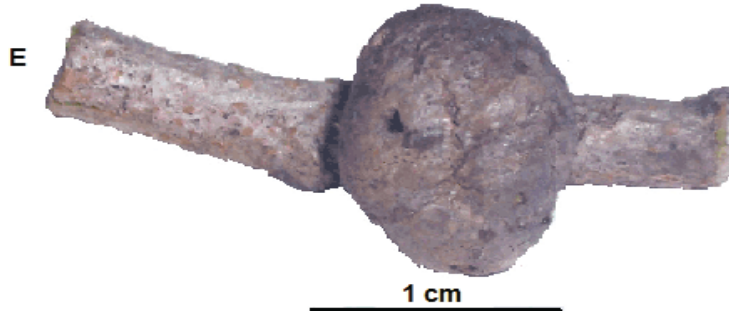

FIGURE 2: Percentage of shoots available in each shoot length class (--- dotted line) and percentage of attacked shoots by the four gall morphotypes (M1, M2, M3 and M4) (-•-continuous line with filled circles) on Eriotheca pubescens. The curve equations of statistically significant values of the percentage of attacked shoots and shoot length class were: M1-y=0.009411+0.022744*x and M3-y $=e^{(-2.19745+0.02724 * x)}$.

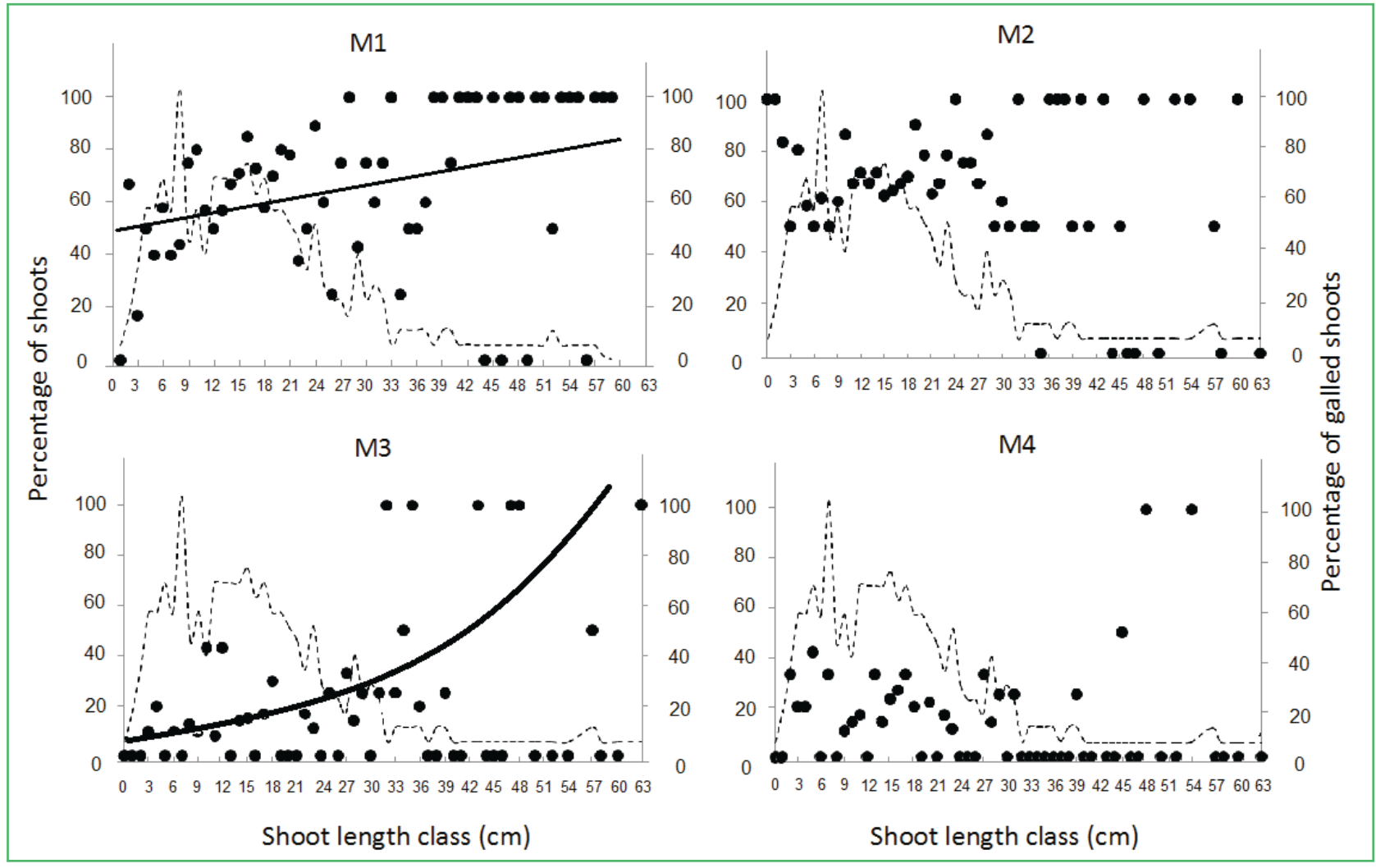


and ramifications (nutritious meristematic tissue) that can be used by gall-inducing insects as oviposition sites (PRICE, 1991; ESPÍRITO-SANTO; FERNANDES, 2007). A meta-analysis verified an increase of $60 \%$ of gall abundance on more vigorous plants, with similar results for stems or leaves (CORNELISSEN et al., 2008). Meristems developing on vigorous branches are a key feature for gall attack success on the host because gall inducers require undifferentiated tissues to induce gall formation (WEIS et al., 1988; OLIVEIRA; ISAIAS, 2010). In addition, a higher tannin concentration (CORNELISSEN; FERNANDES, 2001) and gall mortality has been detected in short branches (ARAÚJO et al., 2011). However, morphotypes 2 and 4 were not influenced by the branch size (M2 - quasi-binomial, $F=0.05, p=0.82$, D.F. $=57 ; \mathrm{M} 4-$ quasi-binomial, $F=$ $0.76, p=0.39$, D.F. $=57$; Figure 2 ). Some authors observed similar results in other systems and concluded that gallinducing species may respond differently to plants that have characteristics linked to nutritional quality, such as shoot vigor, in the same host plant (GONÇALVESALVIM et al., 1999; ARAÚJO et al., 2003).

The E. pubescens density varied from 0.1 to 0.11 individuals $/ \mathrm{m}^{2}$, and there was no relationship between the gall abundance for any morphotype and the E. pubescens density (M1 - Poisson, $p=0.89$, D.F. $=$ 28; M2 - Poisson, $\mathrm{p}=0.92$, D.F. $=28$; M3 - Poisson, $p=0.83$, D.F. $=28$; M4 - quasi-Poisson, $F=0.11, p=$ 0.74 , D.F. $=28$ ). Thus, it is possible that the cecidomyiid insect dispersion determines the attack frequency on hosts at this site (GREZ; GONZÁLEZ, 1995). Grez and González (1995) propose some explanations for the lack of a relationship between insect attack and resource concentration: (i) insects with low dispersion can find sites with higher concentrations of resources because these locations are larger and would not leave these sites because is easy to find the resource and difficult to find the site boundary; and (ii) insects with a high dispersal ability can move easily between sites with different concentration of resources. In this way, the abundance of insects on a plant may be similar among hosts. This last explanation appears to be the case in our study because galling insects can often disperse over long distances with the help of the wind (MENDONÇA-JR; ROMANOWSKI, 2002; LEITE et al., 2009). Moreover, because our study was a natural experiment in which we could not control the distance between sites a priori with different resource concentrations, the similarity of the insect attacks may have been caused by the proximity between the sites (CAPMAN et al., 1990; GREZ; GONZÁLEZ, 1995).

Plant vigor may determine the gall attack pattern for E. pubescens. In contrast, at the intraspecific level, the resource concentration hypothesis does not present itself as a major factor affecting the attack intensity by galling insects in this system due to its dependence on the organism dispersion characteristics, spatial vegetation scale and the patch isolation. Thus, bottle studies on resource concentrations are necessary in the future to evaluate this variable individually in this system.

\section{Acknowledgements}

We thank the two anonymous reviewers for their critiques of this article and hope to have incorporated their many insightful suggestions. We thank C.R. Pereira and F.S. Monção for assistance in the field and with the laboratory work. We thank Pentaurea Camping Club de Montes Claros, Universidade Estadual de Montes Claros (Unimontes) and M.D.M. Veloso for logistic support. A.C.M. Queiroz and J. Tuller are greatly thankful for the scholarship from Coordenação de Aperfeiçoamento de Pessoal de Nível Superior (CAPES), and J.O. Silva acknowledges the Conselho Nacional de Desenvolvimento Científico e Tecnológico (CNPq).

\section{References}

ANTUNES, F. Z. Caracterização climática. Informe Agropecuário, Belo Horizonte, v. 17, p. 15-19, 1994.

ARAúJO, A. P. A.; CARNEIRO, M. A. A.; FERNANDES, G. W. Efeitos do sexo, do vigor e do tamanho da planta hospedeira sobre a distribuição de insetos indutores de galhas em Baccharis pseudomyriocephala Teodoro (Asteraceae). Revista Brasileira de Entomologia, São Paulo, v. 47, n. 7, p. 483-490, 2003.

ARAÚJO, W. S.; RIBEIRO, B. A.; SANTOS, B. B. Abundance of gall-inducing insects in Ouratea hexasperma: response to vigor or escape from hypersensitivity? Journal of Biodiversity and Ecological Sciences, Tonekabon, v. 1, n. 2, p. 161-166, 2011. 
CAMPOS, R. I.; VASCONCELOS, H. L.; RIBEIRO, S. P.; NEVES, F. S.; SOARES, J. P. Relationship between tree size and insect assemblages associated with Anadenanthera macrocarpa. Ecography, Kopenhagen, v. 29, p. 442-450, 2006.

CAPMAN, W. C.; BATZLI, G. O.; SIMMS, L. E. Responses of the common sooty wing skipper to patches of host plants. Ecology, Washington, v. 71, n. 4, p. 1430-1440, 1990.

CARNEIRO, M. A.; BRANCO, C. S. A.; BRAGA, C. E. D.; ALMADA, E. D.; COSTA, M. B. A.; MAIA, V. C; FERNANDES, G. W. Are gall midges species (Diptera, Cecidomyiidae) host-plant specialists? Revista Brasileira de Entomologia, São Paulo, v. 53, n. 3, p. 365-378, 2009.

COELHO, M. S.; ALMADA, E. D.; FERNANDES, G. W.; CARNEIRO, M. A. A.; SANTOS, R. M.; SANCHEZ-AZOFEIFA, A. Gall inducing arthropods from a seasonally dry tropical forest in Serra do Cipó, Brazil. Revista Brasileira de Entomologia, São Paulo, v. 53, p. 404-414, 2009.

CORNELISSEN, T. G.; FERNANDES, G.W. Defence, growthand nutrient allocation in the tropical shrub Bauhinia brevipes (Leguminosae). Austral Ecology, Melbourne, v. 26, p. 246-253, 2001.

CORNELISSEN, T. G.; FERNANDES, G. W.; VASCONCELLOSNETO, J. Size does matter: Variation in herbivory between and within plants and the plant vigor hypothesis. Oikos, Kopenhagen, v. 117, p. 1121-1130, 2008.

COSTA, F. V.; FAGUNDES, M.; NEVES, F. S. Arquitetura da planta e diversidade de galhas associadas a Copaifera langsdorffi (Fabaceae). Ecología Austral, Buenos Aires, v. 20, p. 9-17, 2010.

COSTA, F. V.; NEVES, F. S.; SILVA, J. O.; FAGUNDES, M. Relationship between plant development, tannin concentration and insects associated with Copaifera langsdorffii (Fabaceae). Arthropod Plant Interactions, Dordrecht, v. 5, p. 9-18, 2011.

CRAWLEY, M. J. Statistical computing: an introduction to data analysis using S-plus. Chichester: Jhon Wiley \& Sons Ltda., 2002. $368 \mathrm{p}$.

CUEVAS-REYES, P.; QUESADA, M.; HANSON, P.; DIRZO, R.; OYAMA, K. Diversity of gall-inducing insects in a Mexican tropical dry forest: the importance of plant species richness, lifeforms, host plant age and plant density. Journal of Ecology, London, v. 92, p. 707-716, 2004.

ESPÍRITO-SANTO, M. M.; FERNANDES, G. W. How many species of gall-inducing insects are there on earth, and where are they? Annals of the Entomological Society of America, Lanham, v. 100, n. 2, p. 95-99, 2007.

ESPÍRITO-SANTO, M. M.; NEVES, F. S.; ANDRADE-NETO, F. R.; FERNANDES, G. W. Plant architecture and meristem dynamics as the mechanisms determining the diversity of gall-inducing insects. Oecologia, Berlin, v. 153, p. 353-364, 2007.

FARIA, M. L.; FERNANDES, G. W. Vigour of a dioecious shrub and attack by a galling herbivore. Ecological Entomology, London, v. 26, p. 37-45, 2001.

FERNANDES, G. W.; MARTINS, R. P. As galhas: tumores de plantas. Ciência Hoje, Rio de Janeiro, v. 4, p. 58-64, 1985.

FERNANDES, G. W.; PRICE, P. W. Biogeographical gradients in galling species richness: Tests of hypotheses. Oecologia, Berlin, v. 76, p. 161-167, 1988.
FERNANDES, G. W.; TAMEIRÃO-NETO, E.; MARTINS, E. P. Ocorrência e caracterização de galhas entomógenas na vegetação do Campus Pampulha da Universidade Federal de Minas Gerais. Revista Brasileira de Zoologia, Campinas, v. 5, n. 1, p. 11-29, 1988.

FERNANDES, G. W.; ARAÚJO, R. C.; ARAÚJO, S. C.; LOMBARDI, J. A.; PAULA, A. S.; LOYOLA-JUNIOR, R.; CORNELISSEN, T. G. Insects galls from savanna and rocky fields of the Jequitinhonha Valley, Minas Gerais, Brazil. Naturalia, Rio Claro, v. 22, p. 221-244, 1997.

FLECK, T.; FONSECA, C. R. Hipóteses sobre a riqueza de insetos galhadores: uma revisão considerando os níveis intra-específicos, interespecífico e de comunidade. Neotropical Biology and Conservation, Rio Claro, v. 2, n. 1, p. 36-45, 2007.

GONÇALVES-ALVIM, S. J.; FARIA, M. L.; FERNANDES, G. W. Relationships between four neotropical species of galling insects and shoot vigor. Anais da Sociedade Entomológica do Brasil, Londrina, v. 28, n. 1, p. 147-155, 1999.

GONÇALVES-ALVIM, S. J.; FERNANDES, G. W. Comunidades de insetos galhadores (Insecta) em diferentes fisionomias do Cerrado em Minas Gerais, Brasil. Revista Brasileira de Zoologia, São Paulo, v. 18, n. 1, p. 289-305, 2001.

GREZ, A. A.; GONZÁLEZ, R. H. Resource concentration hypothesis: effect of host plant patch size on density of herbivorous insects. Oecologia, Berlin, v. 103, p. 471-474, 1995.

INBAR, M.; IZHAKI, I.; KOPLOVICH, A.; LUPO, I.; SILANIKOVE, N.; GLASSER, T.; GERCHMAN, Y.; PEREVOLOTSKY, A.; LEV-YADUN, S. Why do many galls have conspicuous colors? A new hypothesis. Arthropod Plant Interactions, Dordrecht, v. 4, p. 1-6, 2010.

HUBERTY, A. F.; DENNO, R. F. Plant water stress and its consequences for herbivorous insects: A new synthesis. Ecology, Washington, v. 85, n. 5, p. 1383-1398, 2004.

JESUS, F. M.; SILVA, J. O.; FAGUNDES, M.; FERNANDES, G. W. Differential female attack and larval performance of a galling cacidomyiid on the host, Astronium fraxinifolium (Anacardiaceae), at contrasting habitats. Entomological News, Philadelphia, v. 122, n. 1, p. 10-21, 2012.

KIMBERLING, D. N.; SCOTT, E. R.; PRICE, P. W. Testing a new hypothesis: Plant vigor and Phylloxera distribution in Wild Grape in Arizona. Oecologia, Berlin, v. 84, n. 1, p. 1-8, 1990

LEITE, G. L.D.; VELOSO, R. V. S.; SILVA, F. W. S.; GUANABENS, R. E. M.; FERNANDES, G. W. Within tree distribution of a gallinducing Eurytoma (Hymenoptera, Eurytomidae) on Caryocar brasiliense (Caryocaraceae). Revista Brasileira de Entomologia, São Paulo, v. 53, n. 4, p. 643-648, 2009.

MENDONÇA-JR, M. S.; ROMANOWSKI, H. P. Life history of the gall-maker Eugeniamyia dispar Maia, Mendonça-Jr. \& Romanowski, 1996 (Diptera, Cecidomyiidae). Brazilian Journal of Biology, São Paulo, v. 62, n. 2, p. 277-283, 2002.

MCCULLAGH, P.; NELDER, J. A. Generalized Linear Models. 2 ed. New York: Chapman and Hall, 1989. 511 p.

NIMER, E.; BRANDÃO, A. M. P. M. Balanço hídrico e clima da região dos cerrados. Rio de Janeiro: IBGE, 1989. 166 p.

PRICE, P. W. The plant vigor hypothesis and herbivore attack. Oikos, Kopenhagen, v. 62, p. 244-251, 1991. 
OLIVEIRA, D. C.; ISAIAS, R. M. S. Redifferentiation of leaflet tissues during midrib gall development in Copaifera langsdorffii (Fabaceae). South African Journal of Botany, Pretoria, v. 76, p. 239-248, 2010.

R DEVELOPMENT CORE TEAM 2.14. 2011. R: a language and environment for statistical computing. Vienna: R Foundation for Statistical Computing, Available from $<$ http://www.rproject.org $>$.

RIZZINI, C. T. Tratado de fitogeografia do Brasil: aspectos ecológicos, sociológicos e florísticos. Rio de Janeiro: Âmbito Cultural Edições Ltda, 1997. 747 p.

ROOT, R. B. The organization of a plant-arthropod association in simple and diverse habitats: the fauna of collard, Brassica oleracea. Ecological Monographs, Washington, v. 43, p. 95-124, 1973.

SANTOS, J. C.; ALMEIDA-CORTEZ, J. S.; FERNANDES, G W. Richness of gall-inducing insects in the tropical dry forest (caatinga) of Pernambuco. Revista Brasileira de Entomologia, São Paulo, v. 55, p. 45-54, 2011.

SANTOS, J. C.; FERNANDES, G. W. Mediation of herbivore attack and induced resistance by plant vigor and ontogeny. Acta Oecologica, Montrouge, v. 36, n. 6, p. 617-625, 2010.
SANTOS, J. C.; SILVEIRA, F. A. O.; FERNANDES, G. W. Long term oviposition preference and larval performance of Schizomyia macrocapillata (Diptera: Cecidomyiidae) on larger shoots of its host plant Bauhinia brevipes (Fabaceae). Evolutionary Ecology, Tucson, v. 22, p. 123-137, 2008.

SANTOS, L. J.; MARMONTEL, C. V. F.; MARTINS, T. M.; MELO, A. G. C. Fitossociologia de cerrado sensu stricto localizado no município de Carbonita-MG. Revista Científica Eletrônica de Engenharia Florestal, Garça, v. 15, n. 1, p. 77-90, 2010.

THORNTHWAITE, C. W. An approach toward a rational classification of climate. Geographical Review, Los Angeles, v. 38, n. 1, p. 55-94, 1948.

WEIS, A. E.; WALTON, R.; CREGO, C. L. Reactive plant tissue sites and the population biology of gall makers. Annual Review of Entomology, Paloalto, v. 33, p. 467-486, 1988

WHITE, T. C. R. A hypothesis to explain outbreaks of looper caterpillars, with special reference to populations of Selidosema suavis in a plantation of Pinus radiata in New Zealand. Oecologia, Berlin, v. 16, p. 279-301, 1974.

WHITE, T. C. R. The abundance of invertebrate herbivores in relation to the availability of nitrogen in stressed food plants. Oecologia, Berlin, v. 63, p. 90-105, 1984. 